

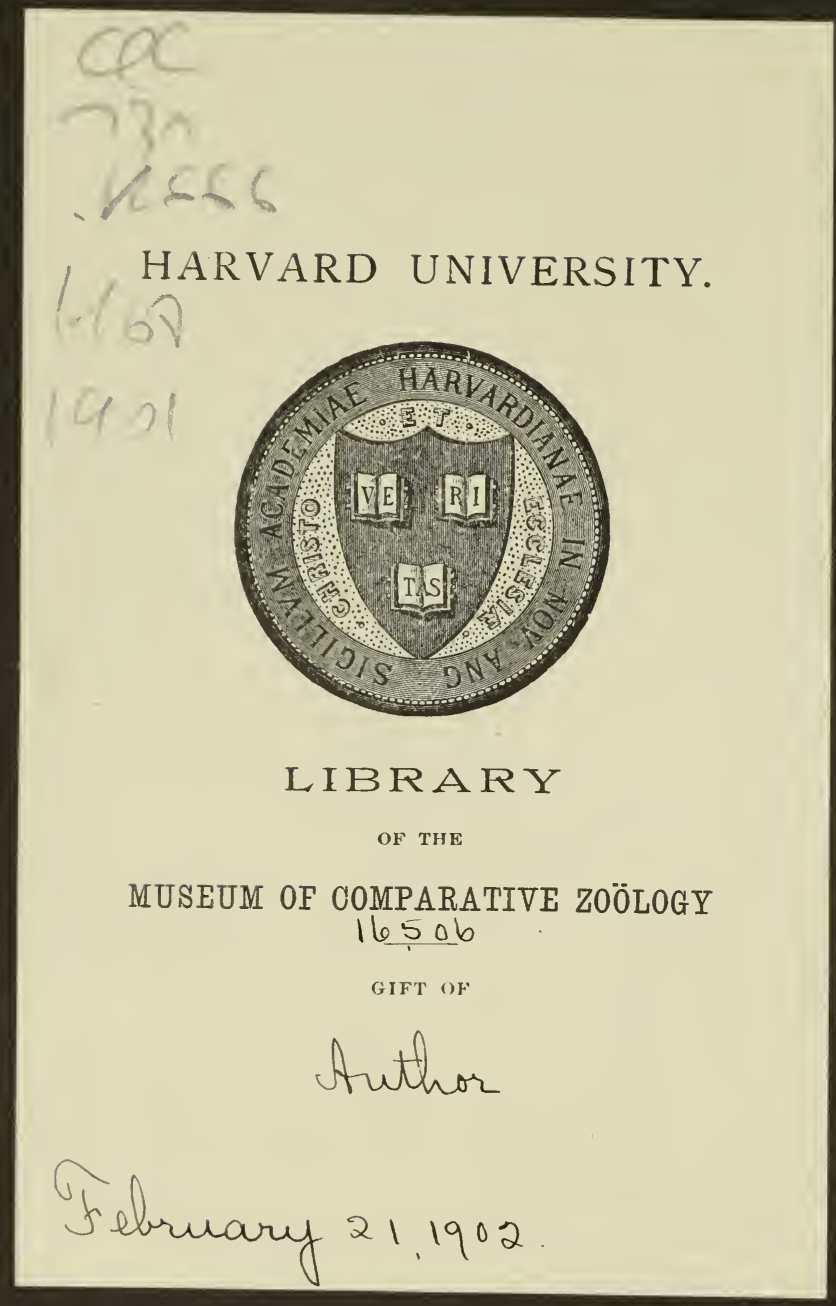


16,506
FE $=1202$

\section{A NEW RACE OF MICROTUS PENASSLLTANIUUS.}

$$
\text { BY }
$$

REGINALD HEBER HOWE, JUNIOR.

From the Proceedings of the Portland Society of Natural History, Vol. II, Part 6, p. 201.

T Portland, Me., Dec. 31, 1901. 


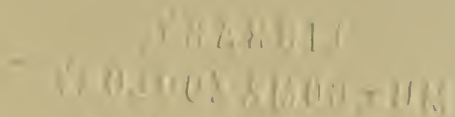

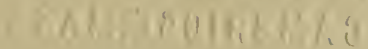




\section{A NEW RACE OF MICROTUS - PENNSILVANICUS.}

BY REGINALD HEBER HOWE, JUNIOR.

(Communicated to the Society, Dec. 5, 1901.)

In July, 1900, with Mr. George C. Shattuck I collected a series of Field Mice on Tumble Down Dick Island, near Long Island, Penobscot Bay, Maine: later, in September Mr. Shattuck secured two more on Long Island near Dark Harbour, and again last summer (1901), he collected five more specimens, one on Tumble Down Dick, and the other four on Long Island. On taking the first specimen out of the trap in 1900, I at once noticed its peculiarity compared with specimens from the mainland, and the series I now have before me leaves no doubt of it being distinct subspecifically from the mainland form.

I take pleasure therefore in naming this new race for my esteemed friend and fellow collector, Mr. George Cheever Shattuck of Boston, Massachusetts.

\section{Microtus penusilvanicus shattucki subsp. nov.}

\section{Penobscot Field Mouse.}

Type from Tumble Down Dick Island, near Long Island, Penobscot Bay, Maine. No. 10,011, adult female, Collection of the Museum of Comparative Zoölogy, Cambridge, Mass. Taken July 10, 1900, by Reginald Heber Howe, Junior and George C. Shattuck.

Geographical Range: Tumble Down Dick, Long Island, and probably other Islands in Penobscot Bay, Maine. 
Subspecific Characters: One of the largest of the Microtus pennsileunicus group. Tail very long, ears prominent, bullae very lurge and globuler, palatine foramina markedly broad and bottle-shuped, Coloration as in II. T). pennsilvanicus, except perhaps slightly darker.

\section{Mensurements of Anults.}

Microtus p. shattuchi: Total length, 176 to 198: Tail, 54 to 62 : Fore foot, 12 to 13 : Ear, 12 to 18.

* Microtus p. pennsilvanicus: Total length, 167 to 171: Tail, $4+$ to 46 .

\section{Measurement of Young.}

Microtus $p$. shuttucki.

Total length, 136 to 165 : Tail, 46 to 53 : Fore foot, 11 to 12: Ear, 12 to 15.

* Taken from Elliot's "Mammals of North America," etc. 


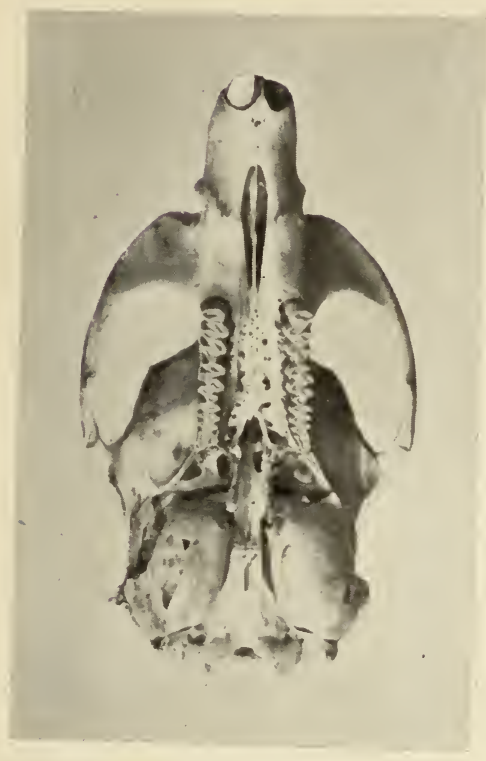

M. PENNSILVANICUS.

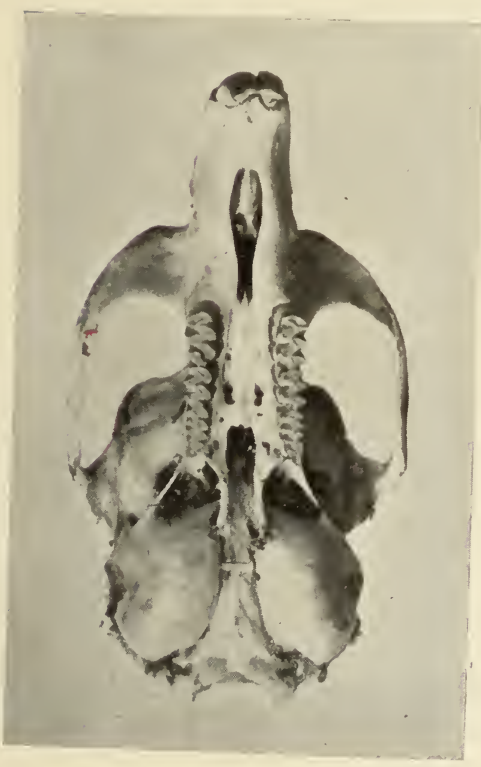

M. P. SHATTUCKI.

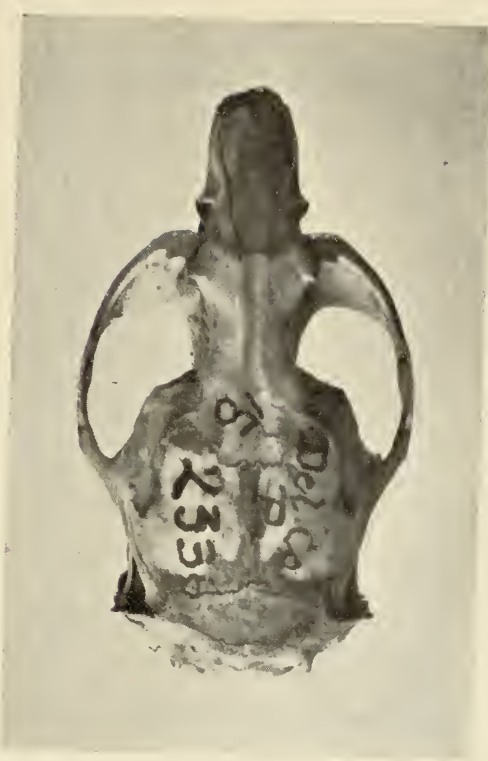

M. PENNSILVANICUS.

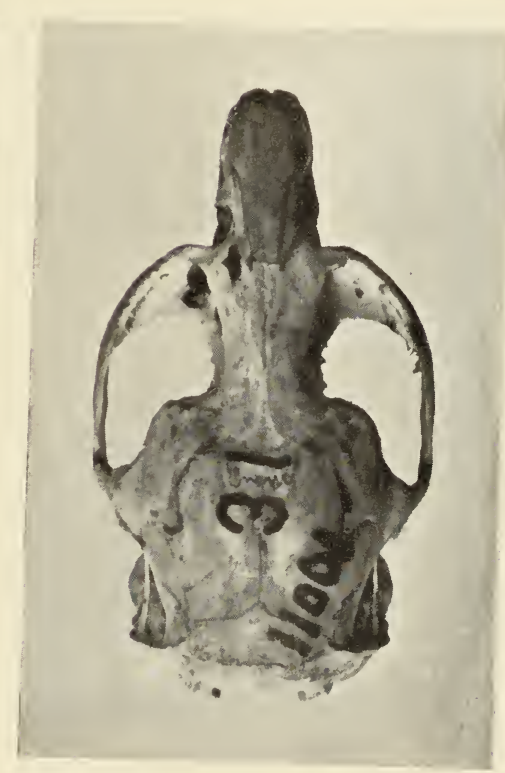

M. P. SHATTUCKI. 







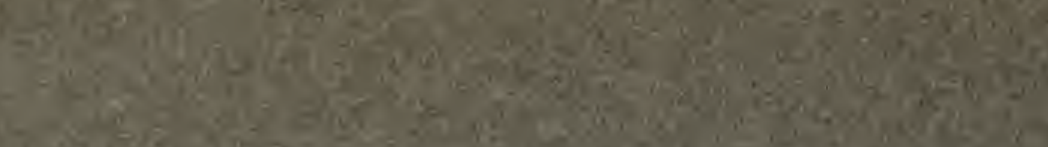

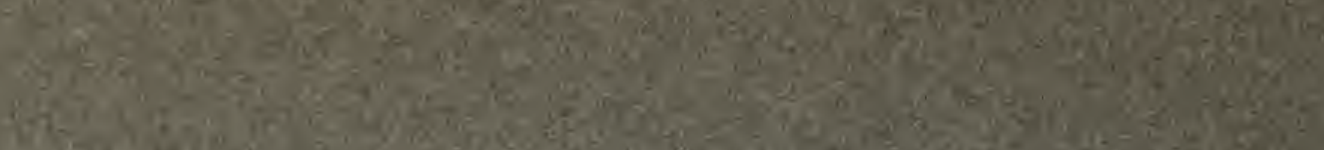
Then 20.

(1)

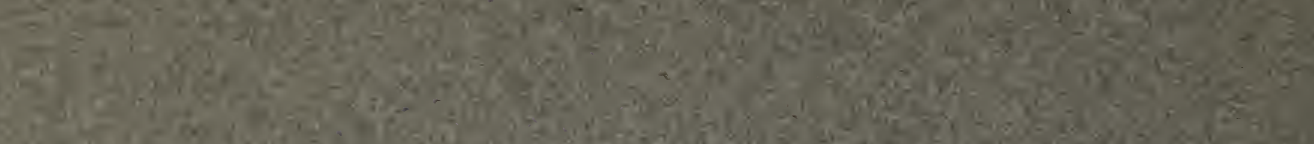
200

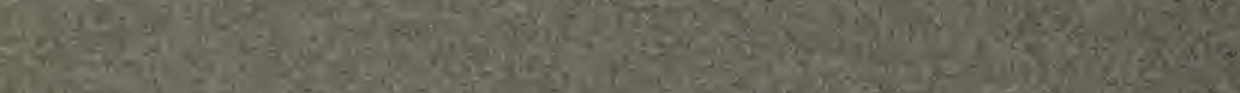

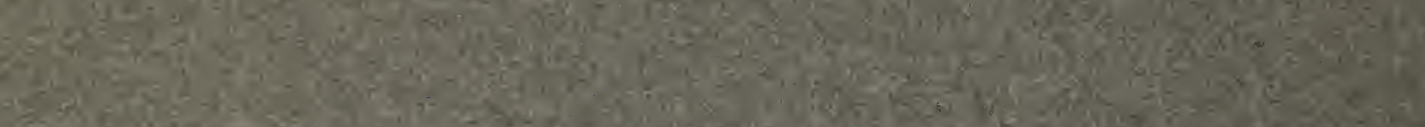

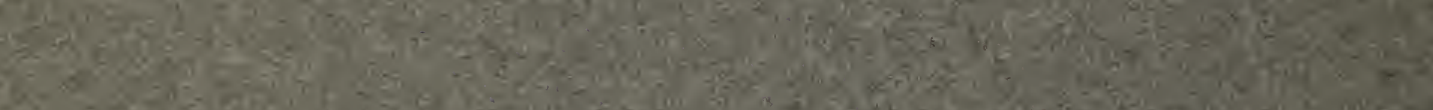

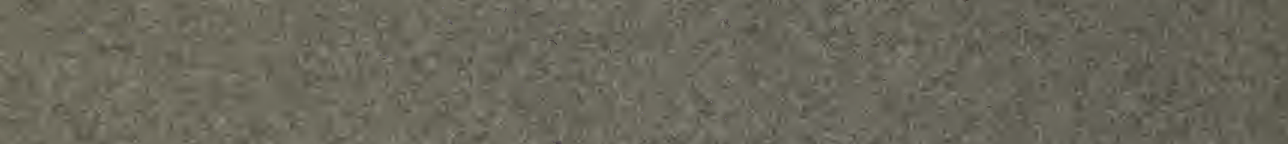

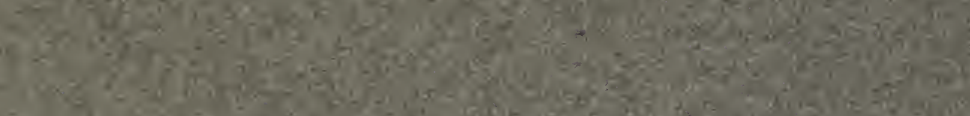

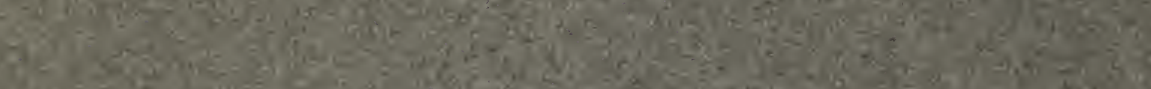

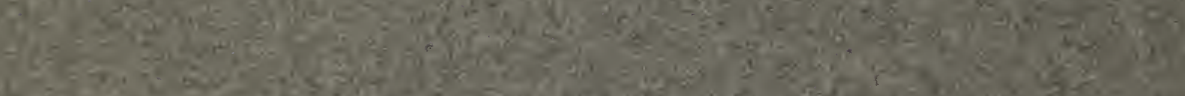

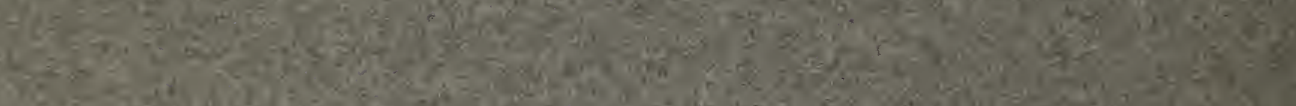

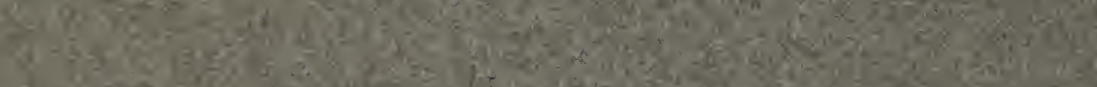

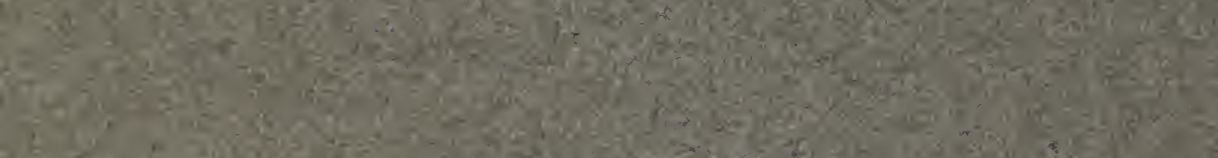

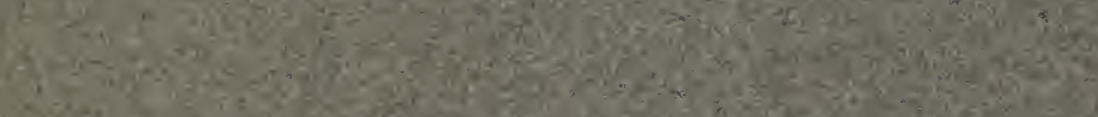

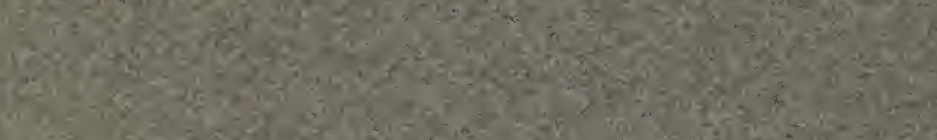

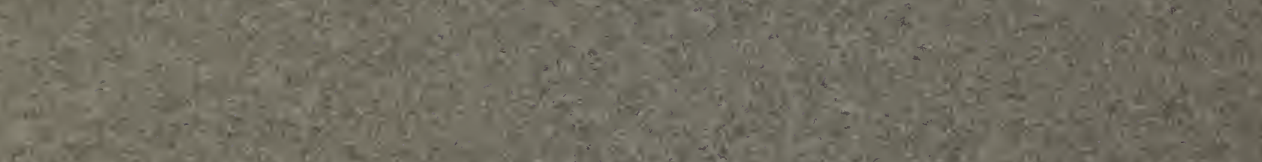

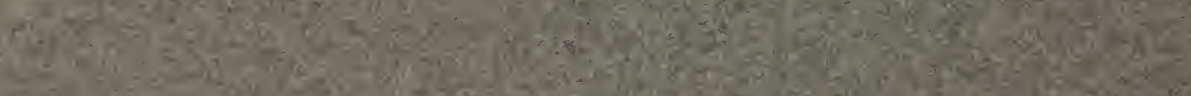

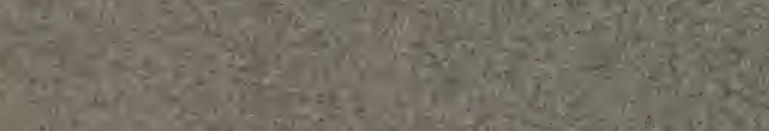

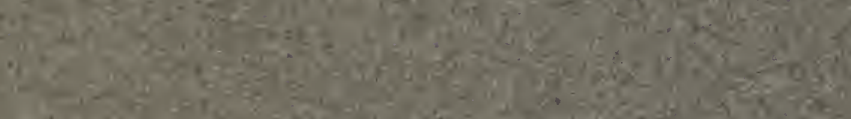

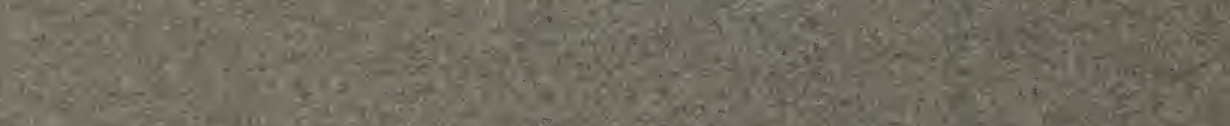

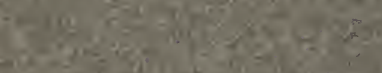

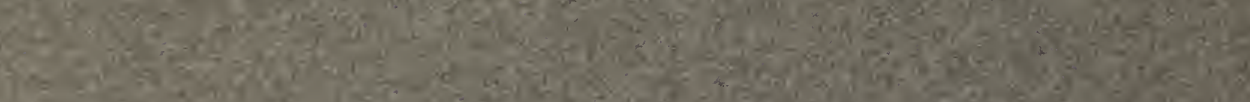

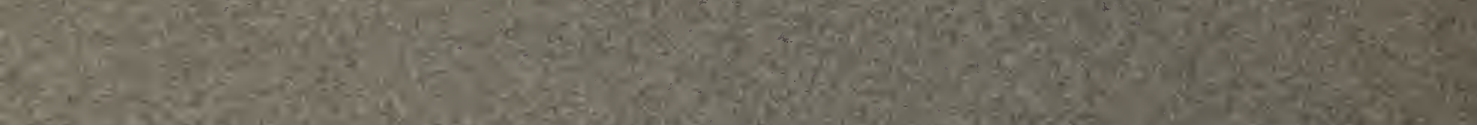

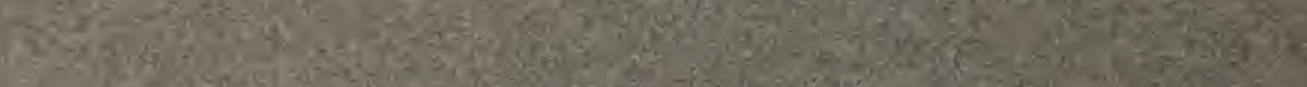

